\title{
PUBLICATIONS RECEIVED.
}

\author{
BOOKS.
}

Dieudonne, A. (1909). Bacterial Food Poisoning. A concise exposition of the etiology, bacteriology, symptomatology, prophylaxis and treatment of so-called ptomaine poisoning. (Translated and Edited, with Additions, by Dr C. F. Bolduan.) New York: E. B. Treat \& Co., 128 pp., $21 \times 14 \mathrm{~cm}$. Price $\$ 1.00$. Cloth.

Dieudonné's valuable little treatise appeared in 1908 and the translation reached us in July 1909. Dr Bolduan has made certain additions relating to prophylaxis applicable to American conditions and has gone further into details of treatment. The material has been somewhat rearranged and an index added. The nine chapters into which the book is divided concern themselves respectively with, (1) meat poisoning due to diseased meat, (2) to decayed meat, (3) sausages, (4) poisoning due to fish and molluscs, (5) to cheese, (6) to ice cream and puddings, (7) to potatoes, (8) canned foods, (9) metals. In each chapter the etiology, symptoms, diagnosis, including bacteriology, prophylaxis and treatment are given. About 100 references are given in the bibliography. The book will prove very useful to those not familiar with the scattered literature on the subject.

ELLIs, D. (1909). Outlines of Bacteriology (Technical and Agricultural). London: Longmans, Green \& Co., 262 pp., 134 illustrations, $22 \times 14 \mathrm{~cm}$. Price 7/6 net. Cloth.

This book is intended for students of technical and agricultural bacteriology and in consequence the pathogenic bacteria are treated somewhat cursorily. In a book of such an elementary character it is diffeult to introduce more than the essentials, and the author appears to have done this with judgment.

Friedemann, U. (1910). Taschenbuch der Immunitätslehre. Leipzig: Joh. Ambrosius Barth, 140 pp., $17.5 \times 11.5 \mathrm{~cm}$. Price 4 Marks.

This little book contains much useful information condensed into a few pages and without pretending to be complete it gives the main methods used in experimental and clinical work on immunity: Technique in relation to animals ; tests with various antibodies, haemolysins, agglutinins, bactericidal substances, precipitins, etc. The book can be safely recommended to those desiring information on our present methods.

James, S. P. (1909). Smallpox and Vaccination in British India. 105 pp., 14 diagrams, $25 \times 19 \mathrm{~cm}$. Price $7 / 6$ net, in India 6 Rupees. London and Calcutta: Thacker, Spink \& Co., 2 Creed Lane, London.

The author presents us with a very interesting history of smallpox inoculation and of the introduction of vaccination into India and details some of the administrative difficulties that have had to be encountered. By means of a series of graphic charts the author demonstrates the beneficial effects that have 
followed vaccination, especially in certain parts of India and in the Army both European and native. The author has acquitted himself well of an exceedingly difficult task and the publication constitutes a valuable contribution to the literature of smallpox.

Newell, A. G. (1909). Blackwater Fever. (Bilious Malignant Tertian Ague.) London: John Bale, Sons \& Danielsson, Ltd., 126 pp., 1 plate (frontispiece), $22 \times 14 \mathrm{~cm}$. Price 5/- net. Cloth.

The author gives an account of his experiences with blackwater fever during nine years spent in highly malarial parts of Bengal. He discusses the views held regarding the etiology of blackwater and describes the symptoms, treatment, etc. He gives full clinical histories of five cases including his own. A series of appendices deal with cognate matters.

Oslowski, DR (1909). Die Schönheitspflege. Für Ärzte und gebildete Laien. 2nd ed., 120 pp., 25 text-figs. Würzburg: Curt Kabitsch (A. Stuber's Verlag). Price 2.50 Marks. Linen.

This booklet, as the sub-title indicates, is written for medical men and educated laymen. It concerns itself with the care of the body and the preservation of its natural beauty. It is an attempt to deal with the subject in a scientific manner and is directed against charlatanism. The book contains much interesting information in condensed form. From the fact that it has already reached a second edition it is obvious that it has met with a demand.

Poweld, A. E. (28. X. 1909). Food and Health. Methuen \& Co., London, W.C. $266 \mathrm{pp}$., $19 \times 13 \mathrm{~cm}$. Price $3 / 6$ net. Cloth.

The author, a Lieutenant in the Royal Engineers, has compiled this book for ordinary laymen. The book contains a good deal of varied information especially regarding diet, ancient and modern, in many parts of the world. The author inclines to vegetarianism.

Raynes, F. W. (1909). Domestic Sanitary Engineering and Plumbing. London: Longmans, Green \& Co., 474 pp., 277 illustrations, $22 \times 14 \mathrm{~cm}$. Price 10/6 net. Cloth.

This book, as stated in the subtitle, deals with domestic water supplies, pump and hydraulic ram work, hydraulics, sanitary work, heating by low pressure, hot water, and external plumbing work. Although intended for students preparing for examination the book should prove of value to a wider circle of readers. The book contains a good many excellent text-figures and useful formulae and altogether presents an excellent appearance.

Wanhilu, C. F. and Beveridge, W. W. O. (1909). The Sanitary Officer's Handbook of Practical Hygiene. London: E. Arnold, 150 pp., $19 \times 13 \mathrm{~cm}$. Price 5/- net. Cloth.

Majors Wanhill and Beveridge of the Royal Army Medical Corps, the authors of this little book, hold respectively the positions of Assistant Professor of Hygiene in the Royal Army Medical College and of Analyst to the Army Medical Advisory Board. The plan of the book is that on which the "training in the Hygiene Laboratories, Royal Army Medical College, is carried out and there found to be satisfactory both for military purposes and for preparation for the examinations for the Diploma in Public Health." This being the case, the book will no doubt meet with a considerable demand. 
WARD, A. R. (1909). Pure Milk and the Public Health. A manual of Milk and Dairy Inspection. Ithaca, N. Y.: Taylor and Carpenter, 218 pp., 17 illustrations, $23 \times 16 \mathrm{~cm}$. Price $\$ 2$ net. Cloth.

In the volume before us, which is dedicated to Veranus A. Moore, the author has brought together facts which will necessarily interest the health officer and "others directly concerned in the crusade for better milk." It is assumed by the author that the reader possesses a general knowledge of bacteriology. The literature of the subject is fully cited in the text and full references are given to the papers quoted. The book is divided into eleven chapters: (1) The contamination of Milk, (2) Changes in Milk caused by Bacteria, (3) Epidemic Diseases transmitted by Milk, (4) Bovine Tuberculosis and other Cattle Diseases, (5) Municipal Sanitary Control of Milk, (6) Pasteurization of Milk, (7) Microscopic Tests of Milk, (8) Bacteriological Examination of Milk, (9) Certified Milk, (10) Analysis of Milk, (11) Adulteration of Milk. An Appendix includes Dairy Ordinances of Berkeley, California, etc. The author is Assistant Professor of Bacteriology and Director of the State Hygienic Laboratory, University of California, which enables him to write with authority. Two chapters are from the pen of M. E. Jaffa, Professor of Nutrition and Director of the State Food and Drug Laboratory, University of California. The writer has condensed a great deal of information into the work, which is a valuable addition to the literature on milk.

The Infuence of Heredity on Disease, with special reference to Tuberculosis, Cancer and Diseases of the Nervous System. A discussion opened by Sir W. S. Church, Bt., K.C.B., M.D., Sir W. R. Gowers, M.D., F.R.S., A. Latham, M.D., and E. F. Bashford, M.D. 142 pp. + xii. Longmans, Green \& Co., London. $26 \times 19 \mathrm{~cm}$. Price $4 / 6$ net. Cloth. (Reprinted from Proc. Roy. Soc. of Medicine, London, Vol. II.)

As stated in the preface to the volume "in view of the importance of determining the influence of heredity as an etiological factor, the Council of the Royal Society of Medicine have thought it right to publish in a separate volume the discussion on this subject held at the Society's rooms" in NovemberDecember 1908. There are many who will welcome the book for the reason above stated. An excellent index prepared by Mr A. L. Clarke materially adds to the value of the book.

\section{BROCHURES.}

Baso, B. D. (1909). The Dietetic Treatment of Diabetes. Allahabad: The Panini Office, Bhuvaneshvari Ashram. 40 pp., $19 \times 13 \mathrm{~cm}$. Price Rs. 1-8-0. Cloth.

Burri, R. (1909). Das Tuscheverfahren als einfaches Mittel aur Lösung einiger schwierigen Aufgaben der Bakterioskopie (Absolute Reinkultur, Spirochaetennachweis u.a.m.). 41 pp., 3 plates, 3 text-figs. Jena: Verlag von Gustav Fischer. Price 3 Marks. $26 \times 17 \mathrm{~cm}$.

The author describes what promises to be a very useful and rapid method of examining fluids, secretions, etc. containing bacteria, spirochaetes (Syphilis) or blood containing protozoa. The method consists in mixing the material to be examined with Indian ink and spreading it upon a slide. The unstained 
spirochaetes etc. stand out clearly on the black background and when photographed give excellent lantern slides, the negative appearing as a diapositive. The method applies particularly well to cultures starting from single bacteria. The author is to be congratulated on the discovery of a valuable method.

Hart, A. H. (1909). How to Cut the Drug Bill. London: John Bale, Sons and Danielsson, Ltd., 83-91 Great Titchfield Street, Oxford Street, W. 47 pp. Price 2/6.

Intended for practitioners who do their own dispensing. Lessens annual cost of drugs dispensed by $20-50 \%$ by cutting out most alcoholic preparations, etc.

IArotzky, A. (1908). Der Idealismus als lebenerhaltendes Prinzip. Wiesbaden: Verlag von J. F. Bergmann, 147 pp.

Paget, Stemphen (1909). The Case against Christian Science. Cassell and Company; Ltd., London, 36 pp. Paper, price $6 d$. net. $20 \times 13 \mathrm{~cm}$.

Contains papers read at the Church Congress, Swansea, and at the Congregational Union's Meeting at Sheffield. Very entertaining reading.

The Medical Inspection of School Children. A Series of Lectures delivered at the West London Post-Graduate College. 62 pp., price 1/-net. London: "The Medical Officer."

This pamphlet includes: The general scheme of Inspection by A. SAunders, M.B.-Examination of skin disease by P. S. ABrahaM, M.D.-Examination of the Eyes by K. Scott, M.D.-Examination of the Ear, Nose, and Throat by H. J. Davis, M.B.-Examination of the Teeth by H. LL. WiLliaMs.

\section{REPORTS.}

Australasian Medical Congress. Transactions of the 8th session held at Melbourne, Victoria, October 1908. Edited by Alex. Lewers, M.R.C.S. etc. Victoria : J. Kernp, Gov't. Printer, Melbourne, 1909.

Yol. I. Transactions: Conjoint Sectional Meetings_Section of MedicineSection of Surgery. $421 \mathrm{pp}$.

Vol. II. Sections of Obstetrics and Gynaecology-Public Health-Anatomy and Physiology-Pathology and Bacteriology. $393 \mathrm{pp}$.

Vol. III. Sections for Diseases of Children-Diseases of the Eye, Ear and Throat-Skin and Radiotherapy-Neurology-Military and Naval Hygiene. Sectional Index. $430 \mathrm{pp}$.

The following papers appear in the Section of Public Health: President's address by J. Mason-Syphilis from the standpoint of Preventive Medicine (1) by A. J. Turner and (2) by B. B. HAM-Colonization of Tropical Australia by R. ARTHUR-Periodicity in Epidemic Disease by J. JAMtesonMedical examination of School Children in Tasmania by S. HALLEY-Examination of School Children by A. H. Clarke-The Maori by M. PoMARE-The Medical Officer of Health by A. THompson-Development of Public Health work in Tasmania by J. S. C. Elkington-Sanitary Administration and Reform by E. G. LeGER-Erson-Public Health Conscience by M. BoorhCooperation between Health Authorities by J. S. C. Elkington-Infant Mortality in a Mining Centre by B. S. Cowen-Petroleum in Insect-borne Diseases by J. S. Purdy-City of Pahran Refuse Destructor by R. H. Fethen- 
stoN and W. Calder-Statistics of Tuberculosis by G. H. KNIBBs-Statistical Opportunities of the Medical Profession by G. H. KnIBBs-Tuberculosis frequency curves by G. H. KNIBBs.

Carpenter, E. G. (1909). Rapport sur la Mortalité Infantile. (Municipalité d'Alexandrie.) Alexandria: Société de Publications Egyptiennes, 40 pp.

ChapiN, C. V. (1909). Fifty-fourth Annual Report upon the Births, Marriages, and Deaths in the City of Providence for the year 1908. 133 pp. City Document No. 20. The Providence Press: Snow and Farnhan Co., City Printers.

Ch ApIN, C. V. (1909). Twenty-sixth Annual Report of the Superintendent of Health of the City of Providence for the year 1908. 115 pp. City Document No. 14. The Providence Press: Snow and Farnham Co., City Printers.

Davies, D. S. (1909). Annual Report of the Medical Officer of Health, and of the General Medical Superintendent of the City Hospitals for 1908. (City and County of Bristol.) Further report on "carrier" Typhoid. Bristol : Bennett Brothers. 178 pp. Boards.

Davies, D. S. and Heaven, J. C. (1909). Annucul Report of the Medical Officers of Health and of the Chief Port Sanitary Inspector, for the year 1908, including Report on Canal Boat Inspection. Bristol : Bennett Brothers Ltd. 49 pp.

Elkington, J. S. C. (1909). Department of Public Health, Tasmania. Annuat Report for the year 1908-9. Hobart, Tasmania: John Vail, Government Printer. $13 \mathrm{pp}$.

Fremantle, F. E. (26. II. 1909). First Annual Report of the School Medical Offeer on the Medical Inspection of Elementary School Children in respect of the year ended 31st December, 1908. 28 pp. Hertfordshire County Council.

HiLl, E. (1909). Report of the Health Officer of the Colony of Natal for the year ended 31st September, 1908. Pietermaritzburg: Times Printing and Publishing Co. Ltd., 45 pp., price $9 d$. $33 \times 21 \mathrm{~cm}$.

Houston, A. C. (II. 1909). The storage of Raw River Water antecedent to Filtration. Third Report on research work. Metropolitan Water Buard. Metropolitan Water Board, London, $47 \mathrm{pp}$. $33 \times 21 \mathrm{~cm}$.

Houstov, A. C. (VI. 1909). Report on the results of the Chemical and Bacteriological Examination of the London Waters for the Twelve Months ended 3Ist March, 1909. Metropolitan Water Board: Third Annual Report. 42 pp.

Hodston, A. C. (VI. 1909). The vitality of the Cholera Vibrio in artificially infected samples of raw Thames, Lee and New River Water, with special reference to the question of storage. Metropolitan Water Board: Fourth Research Report. $18 \mathrm{pp}$.

II. Internationale wissenschaftliche Lepra-Konferenz, abgehalten $v$. 16 bis 19 August 1909, in Bergen (Norwegen). Mitteilungen u. Verhandl, herausg. v. Dr. H. P. Lie (General-Sekretär) Bd. I, 153 pp., 2 portraits and 3 maps. Leipzig: Joh. Ambr. Barth; Paris: Masson \& Cie ; London: Williams \& Norgate; New York: Lamke \& Buechner. Price (Cloth) 8 Marks. $28 \times 20 \mathrm{~cm}$.

The first volume of the reports and papers of the second international scientific conference on Leprosy is adorned by two excellent portraits of Danielssen and Boeck. Ehlers and Verdier have written a chapter on the geographical distribution of Leprosy, G. Armauer Hansen and H. P. Lie give account of the history of Leprosy in Norway (2 maps and several figures), whilst Sederholm, Bjarnhjedinsson and Fagerland write respectively on 
Leprosy in Sweden (1 map), Iceland and Finland. It seems scarcely necessary to say that the publication is one of the first importance to leprologists all over the world. The printing and illustrations leave nothing to be desired.

КосH, R., Beck, M. and Kleine, F. (1909). Bericht über die Tätigkeit der zur Erforschung der Schlafkrankheit im Jahre 1906-07 nach Ostafrika entsandten Kommission. 319 pp., 5 pls., 180 figs. (Also published in Arb.a.d. Kaiserl. Gesundheitsamte, xxxI., as the 1st Fasciculus.) Berlin: Verlag von Julius Springer.

The report on sleeping sickness by the German Commission is one of the first importance and should be consulted by all who concern themselves with the disease. It deals with the etiology, symptomatology, treatment and prevention of the disease and includes, besides maps, a large number of most excellent illustrations. The clinical histories of 301 cases of sleeping sickness are included in the appendix. The report is a monument of industry and incorporates a very large amount of valuable original work.

Liston, W. G. (1909): Report of the Bombay Bacterioloyical Laboratory for the year 1908. Bombay: Printed at the Government Central Press. 15 pp. Price 5 annas, or $6 d$.

E. Merck's annual report of recent advances in Pharmaceutical Chemistry and Therapeutics, 1908, vol. xxII., 348 pp. (Published VIII. 1909.) E. Merck, Chemical Works, Darmstadt. Price $1 / 6$.

Copies of this publication, of which there are a limited number, may be obtained free by medical men on application to E. Merck, 16 Jewry St, London. The report brings together a great deal of useful information in the form of abstracts of the literature which appeared in 1908.

Rapports à M. le Préfet, Préfecture du Dép. de la Seine. Direction des Affaires Municipales. Bureau Administratif des Services d'Hygiène de la Ville de Paris. Paris: Imprimerie et Librairie Centrales des Chemins de Fer. Imprimerie Chaix, Rue Bergère 20.

(a) $(1908,70 \mathrm{pp}.) \quad 1^{0}$ Sur quelques ilots de maisons tuberculeuses (20 déc. 1904);

$2^{0}$ Sur la répartition de la mortalité par la tuberculose pulmonaire dans les maisons de Paris, du 1 jan. 1894 au 31 déc. 1904 (20 mars 1905);

$3^{0}$ Sur la répartition de la tuberculose pulmonaire dans les maisons de Paris, pendant l'année 1905 (19 mars 1906);

$4^{0}$ Sur les enquêtes effectuées en 1905 dans les maisons signalées comme foyers de tuberculose (20 mars 1906).

(b) (1909, 7 pp.) Enquêtes effectuées en 1908 dans les maisons signalées comme foyers de tuberculose.

(c) $(1909,127$ pp.) Recherches effectuées au Bureau du Casier Sanitaire pendant l'année 1908 relatives à la répartition de la tuberculose et du cancer dans les maisons de Paris.

Stanley, A. (1909). Annual Report of the Shanghai Municipal Council (Health Department) for 1908 . Shanghai : Kelly and Walsh. $41 \mathrm{pp}, 32 \times 20 \mathrm{~cm}$.

Simpson, W. J. and others (II. 1909). Report on Plague in the Gold Coast in 1908. London: J. and A. Churchill, 7 Great Marlborough St. 55 pp. Price 2/- net. Boards. $33 \times 25 \mathrm{~cm}$. 
Third Report of the Wellcome Research Laboratories at the Gordon Memorial College, Khartoum. Director, Andrew Balfour. Published for the Dept. of Education, Sudan Government, Khartoum, by Baillière, Tindall and Cox, 8 Henrietta St., Covent Garden, London, 1908. 477 pp., 48 plates, 218 text figures. $28 \times 20 \mathrm{~cm}$. Cloth. Price £1 1s. $0 d$.

Review of some of the recent advances in Tropical Medicine, Hygiene and Tropical Veterinary Science, with special reference to their possible bearing on Medical, Sanitary and Veterinary Work in the Anglo-Egyptian Sudan; being a supplement to the Third Report etc. by Andrew Balfour and R. G. Archibald. $251 \mathrm{pp}$. (same size as the preceding), 1 map. Price 10/6.

This monumental report contains a large amount of valuable and original material. It includes papers by Leiper on parasitic worms, by Theobald on mosquitoes, by Werner on reptiles, by Waterston on Anthropology, by Balfour on trypanosomiasis, piroplasmosis and spirochaetosis, and on public health problems in Khartoum. Ensor and Archibald deal with Sleeping Sickness, Cummins and Bousfield with Kala-azar, King with Entomology, Wenyon with protozoology, etc. Numerous and for the most part excellent coloured plates and figures illustrate the volume. Whereas the First and Second Reports were distributed gratuitously a charge, which has been calculated as low as possible, will be made for the Third and subsequent Reports. The form in which the Report and Supplement are issued is excellent.

\section{NEW PERIODICALS.}

The British Health Review, vol. I., No. 1 (15th April, 1909). Edited by Mrs. L. Hodgkinson. $36 \mathrm{pp}$., price $3 d$. monthly; 4/- per annum, post free. London: Published by British Health Review Co., 21 Paternoster Square, E.C.

It is difficult to understand to what class of readers the journal will appeal unless it be found among frequenters of vegetarian restaurants.

Bulletin of the Pasteur Institute of Southern India. No. 1, 1908. (Published under the authority of the Central Committee of the Association.) $34 \mathrm{pp} .33 \times 21 \mathrm{~cm}$. Madras, 1909: Printed by the Superintendent, Government Press.

Contains short notes by J. W. Cornwall and M. Kesava Pai on: The influence of cyllin on rabies virus-the diagnosis of rabies in inoculated animals-the measure of immunity in men and animals-the degree of infectivity of the various parts of the central nervous system-Negri bodies-rabies toxins-histology of the blood in rabies-susceptibility of guinea-pigs and their immunization-action of chloroform on fixed virus-the infectivity of peripheral nerves in rabies, etc.

Hygiene and Physical Education, April, 1909. Vol. I., No. 2, 127 pp. Published by The F. A. Bassette Company, Springfield, Massachusetts. The second number, the first to reach us for review, contains:

Ten Commandments of Schoolhouse Construction by WM. E. Chancellor, Supt. of Sehools, City of South Norwalk, Conn. (illustrated).-The Problems of Hygiene and the Province of the State Normal School by HoMER H. Seerley, LL.D., Iowa State Normal School.-School Hygiene and Efficiency by Arthur E. Bennett, Ph.D., Upper Iowa University.--School Hygiene and Community Health by Jessie Benton Montgomery, Indiana State Normal 
School.-The School and the Germ-Carrier by Prof. Edwis O. Jordan, University of Chicago.-Prophylaxis in the Practice of the School Superintendent by Edwin L. Srevens, L.H.D., City of New York.-A Lesson from Medical Inspection of Schools by Geo. H. MakTIN, LL.D., Secretary Massachusetts Board of Education.-American School Hygiene Association by Dr Tros. A. Storex, Sec'y.-Function and Administration of Medical Supervision in the School by Dr J. E. RAYcroFr, University of Chicago.

Sanidad y Beneficencia Boletin Oficial de la Secretaria, Vol. I., No. 1 (appeared April 1909), 156 pp., 11 figs., 19 photographs. No. 2, pp. 157-339. Published by Dr E. B. Barnet under the direction of the officials Drs Matias Duque, Juan Guiteras and Juan M. Plá. Editorial Office in the Secretaria de Sanidad y Beneficencia, Habana, Cuba.

The opening number of this new monthly periodical contains: Notes in regard to yellow fever and tuberculosis in Cuba during the past years by J. Guiteras.-The division of charities by J. M. PLA.-Tributo de gratitud (with portraits of all those concerned in the great discoveries concerning yellow fever) by E. B. BARNET.-Etiology of yellow fever and destruction of mosquitoes by A. Agramonte.-Clinical Observations on the different varieties of rings obtained by the Heller reactive by E. F. RODRIGUEZ.--Statistics relating to Public Health and Demography in Cuba, Meteorological Reports, etc. The scientific papers appearing in the second number are: Symptomatology and diagnosis of yellow fever by J. Goimeras.-Special diagnosis of yellow fever with reference to mild cases by M. S. LeBredo.-Preliminary note on the agent of Trachoma by L. E. Finlay and J. Cartaya. The Journal is published in Spanish-English-French and presents an excellent appearance.

\section{REPRINTS.}

Brazil, V. (1909). Serumtherapia anti-ophidica. Revista Medica de S. Paulo, No. 15, 13 figs., 43 pp. reprint.

Clemmont, G. (1909). Experimental research on the hypodermic and intra-venous injection of Vichy-water taken at the spring. Centre Médical (Riom). $14 \mathrm{pp}$. reprint.

Crendiropodlo, M. (1909). Une Fièvre des Pays chauds non encore décrite. Presse Médicale, No. 13, 16 pp.

IARotzkY, A. (1907). Lokale Erscheinungen bei passiver Immunität gegen Schweinerotlauf und Infektion. Centralbl. f. Bakteriol., 1 Abt. Bd. xuIv., Orig. pp. 76-89, 7 figs.

Pinzani, G. (1909). Proposta di un nuovo metodo per la determinazione della luce. Rivista d' Ingegneria Sanitaria (Biella), 7 pp. reprint.

Sewastianoff, Dr (1909). Die phagozytäre Tätigkeit der roten Blutkörperchen und der Blutplättchen (Bizzozero). Wien. klin. Rundschau, Nos. 26-29, 19 figs., $14 \mathrm{pp}$. 